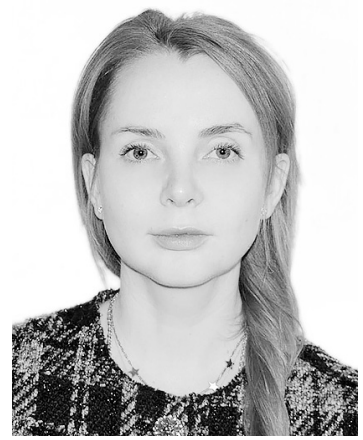

\title{
ЮРИДИЧНА ВІДПОВІДАЛЬНІСТЬ ЗА ВЧИНЕННЯ КРИМІНАЛЬНИХ ПРОСТУПКІВ
}

\section{АЛЕКСЕСВА-ДАНИЛЕНКО Юлія Володимирівна - аспірант Харківського національного університету внутрішніх справ}

DOI 10.32782/LAW.2020.2.19

У статті розглянуті питання настання юридичної (кримінальної) відповідальності за вчинення кримінальних проступків. Наголошено, щзо єдиною підставою юридичної (кримінальної) відповідальності є вчинення особою правопорушення за умови наявності в Кримінальному кодексі Украӥни норми, що передбачає міру відповідальності за вчинення такого діяння.

Юридична (кримінальна) відповідальність $\varepsilon$ системою кримінально-правового впливу на правопорушників і інших членів суспільства з метою запобігання вчиненню нових правопорушень. Пропонується до заходів юридичної відповідальності додати $i$ такий захід, як обов'язкове відикодування збитків (матеріальних $i$ моральних), завданих кримінальним проступком.

Вид покарання як міру юридичної відповідальності за кримінальні проступки визначає тільки суд $i$ в межах, встановлених законом. Основним видом відмежування юридичної відповідальності за вчинення кримінального проступку від відповідальності за злочин $є$ ступінь суспільної небезпеки вчиненого діяння.

Ключові слова: юридична відповідальність, права и свободи, кримінальні проступки, мета відповідальності, фбункиії відповідальності, вік, підстави.

\section{Вступ}

3 прийняттям у 2012 році Кримінального процесуального кодексу України була зроблена спроба запровадити поняття «кри- мінальні правопорушення», у якому були 6 об'єднані дві категорії кримінального права - кримінальний злочин і кримінальний проступок.

Однак, як зауважує Скачко О.В., ці новації вступили в протиріччя з іншими нормами кримінального права, що зумовило конкуренцію правових норм та шкідливі для практики правосуддя юридичні колізії. ${ }^{1}$

Знадобилося 8 років різних дискусій 3 розгляду кількох законопроєктів до того, як 1 липня 2020 року набув чинності Закон України «Про внесення змін до деяких законодавчих актів України щодо спрощення досудового розслідування окремих категорій кримінальних правопорушень». ${ }^{2}$

У ст. 11 Кримінального кодексу України внесено зміни, які визначають «кримінальне провадження» (єдине як для злочинів, так і для проступків) - «суспільно небезпечне винне діяння (дія чи бездіяльність), вчинене суб'єктом кримінального правопорушення». У ст. 12 КК України встановлено два види кримінальних правопорушень (кримінальні проступки та злочини) та дано їх визначення.

\footnotetext{
${ }_{1}^{1}$ О.В. Скачко Правова визначеність щодо інституту кримінальних проступків та процесуальної форми пізнання. Актуальні проблеми держави і права. 2018, С. 127 (127 - 133 ст.).

2 Закон України «Про внесення змін до деяких законодавчих актів України щодо спрощення досудового розслідування окремих категорій кримінальних правопорушень»//Відомості верховної Ради України, 2019. - №17, Ст.71.
} 
Аналіз останніх досліджень та публікацій

Юридична відповідальність за вчинення кримінальних проступків розглядалася окремими вченими-юристами, зокрема В.I. Борисовим, С.В. Ківаловим, І.П. Голосніченко, В.М. Куц, В.О. Навроцьким, О.В. Остроглядом, В.О. Туляковим, П.А. Фрісом, М.І. Хавранюком та іншими.

Aле дослідження вказаних учених проблем 3 провадження кримінальних проступків були зроблені ще до прийняття змін до Кримінального кодексу України, а після введення законодавства про кримінальні проступки в дію, відповідних публікацій не було. А між тим низка проблемних питань щодо реалізації правових норм, регламентуючих кримінальні проступки, залишаються малодослідженими, зокрема, юридична відповідальність за вчинення кримінальних проступків.

Мета статті полягає в тому щоб проаналізувати заходи юридичної відповідальності, передбачені Кримінальним кодексом України, за вчинення кримінальних проступків.

\section{Виклад основного матеріалу}

За офіційними повідомленнями $\mathrm{MBC}$ України, більше 50 \% усіх зареєстрованих кримінальних правопорушень перейшли у категорію кримінальних проступків. ${ }^{3}$

Впровадження кримінальних проступків свідчить про гуманізацію кримінального законодавства,оскільки відповідні зміни посилюють забезпечення прав людини під час розслідування та пом'якшують юридичні наслідки, а кримінальний проступок не сприймається як кримінальний злочин.

Особу, яка вчинила кримінальний проступок, можна затримувати лише тоді, коли вона:

- відмовляється припинити вчинення проступку або чи чинить опір працівнику правоохоронного органу;

- намагається втекти з місця події;

- відмовляється під час переслідування виконувати законні вимоги поліцейських;

3 Звіт МВС України за 2019-2020. https://mvs.gov.ua/ ua/infographic
- перебуває в стані алкогольного чи наркотичного сп'яніння та може завдати шкоди собі чи оточенню;

- ухиляється від органів досудового розслідування чи суду.

До особи, яка підозрюється у вчиненні криминального проступку, можуть бути застосовані тільки два види запобіжних заходів - особисте зобов'язання та особиста порука.

Юридична відповідальність за вчинення кримінального проступку, наступає лише при наявності причинного зв'язку між діянням і наслідками.

Юридична відповідальність - це вид соціальної відповідальності, що полягає в застосуванні державою до правопорушників певних заходів примусу, передбачених санкціями правових норм. ${ }^{4}$

При вчиненні кримінального проступку єдиною підставою для юридичної відповідальності є склад правопорушення. Якщо в поведінці суб'єкта не виявлено ознак правопорушення, то така особа не підлягає юридичній відповідальності.

Залежно від характеру правопорушення і його наслідків виділяють чотири види юридичної відповідальності: кримінальну, адміністративну, цивільну й дисциплінарну. Кримінальна відповідальність настає за вчинення кримінального провадження. Адміністративна відповідальність настає за вчинення адміністративних проступків, передбачених Кодексом України про адміністративні правопорушення. Цивільна відповідальність - це відповідальність, яка настає за невиконання або неналежне виконання зобов'язань за договором або заподіяння шкоди в позадоговірних відносинах. Дисциплінарна відповідальність настає за вчинення дисциплінарних проступків.

Кримінальна відповідальність за кримінальні правопорушення $є$ найбільш тяжкою за наслідками. Повний перелік злочинів і кримінальних проступків в Україні міститься в Особливій частині Кримінального кодексу України. Порядок притягнення до кримінальної відповідальності за вчинення

\footnotetext{
Юридична відповідальність: підстави, види, цілі. https://pidru4niki.com/ 2008021559031/ pravo/ yuridichna_vidpovidalnist_pidstavi_vidi_tsili
} 


\section{Кримінальне право, кримінальний процес та криміналістика}

кримінальних правопорушень (кримінальних проступків і злочинів) встановлений Кримінальним процесуальним кодексом України ${ }^{5}$.

У Кримінальному кодексі України міститься 98 складів кримінальних проступків. Кримінальним законодавством встановлені три основні види покарання за вчинення кримінальних проступків, а саме:

а) штраф до 51 тис. грн..;

б) громадські чи виправні роботи;

в) арешт чи обмеження волі. В окремих випадках можливе додаткове покарання позбавлення права обіймати певні посади чи займатись певною діяльністю.

За вчинення кримінального проступку особа не може бути позбавлена волі, а після відбуття призначеного покарання вважається не судимою.

А.С. Макаренко зазначає, що за своєю природою кримінальний проступок є кримінальним правопорушенням меншого ступеня суспільної небезпечності у порівнянні зі злочинами невеликої тяжкості, їх вчинення своїм наслідком мають порушення прав та інтересів людини та громадянина, юридичної особи тощо. У такому випадку є доцільним вести мову про відновлення таких порушених прав. Обов’язок відшкодування шкоди, як вид покарання за кримінальні проступки, був би спрямований на компенсацію наслідків вчинення кримінального проступку та відновлення порушеного стану об'єкта посягання.

Юридична відповідальність за вчинення кримінальних проступків застосовується $з$ метою охорони прав і свобод людини, законних інтересів суспільства і держави, попередження інших правопорушень i підтримання правопорядку. Притягнення до юридичної відповідальності забезпечує захист конституційно закріплених прав i свобод людини; прав та законних інтересів юридичних осіб незалежно від форм власності; інших цінностей громадянського суспільства і держави шляхом притягнення правопорушників до відповідальності.

Юридична відповідальність зобов’язує та сприяє відновленню порушених прав людини і законних інтересів суспільства і держави. Засобами юридичної відповідальності за вчинення кримінальних проступків здійснюється виховання особи і суспільства, поширюється правова освіта, підвищується правова свідомість та правова культура в суспільстві, в тому числі і виправлення й перевиховання правопорушників.

Суб'єкти юридичної (кримінальної) відповідальності за вчинення кримінальних проступків - це фізичні особи, що вчинили проступок одноособово чи колективно (групою) та досягли певного віку з якого розпочинається юридична відповідальність за ті чи інші кримінальні проступки та здатні за своїм психічним станом нести таку відповідальність.

Мета юридичної відповідальності за вчинення кримінальних проступків реалізується через іiї функції.

Функції юридичної відповідальності основні напрямки застосування примусових заходів щодо правопорушників з метою забезпечення реалізації права, попередження правопорушень, покарання і виправлення правопорушників, відновлення порушених прав. ${ }^{7}$

Основні функції юридичної відповідальності за вчинення кримінальних проступків формулюються наступним чином:

- правоохоронна, яка полягає в охороні прав і свобод особи, суспільства у попереджені правопорушень, тобто в утриманні особи від вчинення правопорушень, в охороні громадського порядку і безпеки;

- правозахисна - реалізується через заходи забезпечення захисту прав і свобод особи, законних інтересів суспільства, від зловживання правом;

- правопоновлювальна - як різновид правозахисної функції, яка спрямована на відновленні, порушених кримінальним проступком, суб'єктивних прав, примусовій реалізації фізичною чи юридичною особою належних юридичних обов’язків;

- каральна - виражається в застосуванні певних обмежень прав суб'єкта кримінального проступку, позбавленні його певних благ (матеріальних чи нематеріальних), як покарання за вчинення шкоди завданої кримінальним проступком;

- правовиховна - розкривається у вихованні членів суспільства у дусі поваги до 
державних законів, виправленні і ресоціалізації правопорушників.

\section{Висновок}

Юридична відповідальність за вчинення кримінальних проступків наступає у відповідності 3 кримінальним законодавством, але, в окремих випадках, вона може поєднуватися із заходами цивільно-правової та адміністративної відповідальності.

За загальним правилом кримінальній відповідальності підлягають особи, яким до вчинення кримінального правопорушення виповнилося 16 років (ч.1 ст. 22 КК України).

Досягнення встановленого законом віку є однією 3 обов'язкових умов притягання особи до кримінальної відповідальності. За окремі правопорушення закон передбачає i знижений вік з якого може наставати кримінальна відповідальність.

Кримінальну відповідальність батьків за кримінальні проступки вчинені малолітніми та неповнолітніми, законом не встановлено. Aле батьки несуть цивільну відповідальність за шкоду, заподіяну малолітніми та неповнолітніми дітьми при вчиненні правопорушення.

Підставою юридичної кримінальної відповідальності за вчинення кримінального проступку $\varepsilon$ вчинення особою правопорушення за умови наявності кримінальної норми, що встановлюе міру відповідальності за нього. Юридична відповідальність за вчинення кримінального проступку - це заходи державного примусу, які реалізується через застосування санкцій відповідних норм Кримінального кодексу України.

\section{Лiтература}

1. Скачко О.В. Правова визначеність щодо інституту кримінальних проступків та процесуальної форми пізнання. Актуальні проблеми держави і права. - 2018, С. 127 (127 - 133 ст.).

SUMMARY
The article deals with the issues of legal
(criminal) liability for criminal delicts/ It is
emphasized that the only basis for legal (criminal)
liability is the commission of an offence by a person
provided that the Criminal Code of Ukraine
contains a provision that provides for the measure
of liability for the commission of such act.
Legal (criminal) liability is a system of criminal
legal influence on offenders and other members of
society in order to prevent the commission of new
offenses. It is proposed to add to the measures of
legal responsibility such a measure as mandatory
compensation for losses (material and moral)
caused by a criminal delict.
The type of punishment as a measure of legal
liability for criminal delicts is determined only by
the court and within the limits established by law.
The main type of delimitation of legal liability for a
criminal delict and liability for a crime shall be the
degree of public danger of the committed act.

2. Макаренко А.С. Теоретичні основи пеналізації кримінальних проступків. Вісник асоціації кримінального права України. 2014, № 2 (3). - С.80 (75- 87 с.).

3. Закон України «Про внесення змін до деяких законодавчих актів України щодо спрощення досудового розслідування окремих категорій кримінальних правопорушень»//Відомості верховної Ради України, 2019. - №17, Ст.71.

4. Звіт МВС України за 2019-2020. https:// mvs.gov.ua/ua/infographic

5. Юридична відповідальність: підстави, види, цілі. https://pidru4niki. com/2008021559031/pravo/yuridichna vidpovidalnist_pidstavi_vidi_tsili

6. Кримінальний процесуальний кодекс. https://zakon.rada.gov.ua/laws/show/4651 17\#Text

7. Мета і функції юридичної відповідальності. https://studfile.net/preview/5109957/ page: $116 /$ 